\title{
Survival probability estimates for immature green turtles Chelonia mydas in the Bahamas
}

\author{
Karen A. Bjorndal ${ }^{1, *}$, Alan B. Bolten ${ }^{1}$, Milani Y. Chaloupka ${ }^{2}$ \\ ${ }^{1}$ Archie Carr Center for Sea Turtle Research and Department of Zoology, University of Florida, PO Box 118525, Gainesville, \\ Florida 32611, USA \\ ${ }^{2}$ Department of Economics, University of Queensland, Brisbane, Queensland 4072, Australia
}

\begin{abstract}
Green turtles Chelonia mydas in the Atlantic undergo a complex series of developmental migrations, moving long distances among foraging grounds. The study of the ecology and demography of these foraging populations is hampered by a lack of estimates of survival probabilities for immature stages. In addition, for all species of sea turtles, estimates of survival probabilities have repeatedly been identified as the greatest requirement for improving models of population dynamics and plans for the management and conservation of these endangered and threatened species. We use data from long-term capture-mark-recapture studies of 2 sampling populations of immature green turtles in the Bahamas-Union Creek, Great Inagua from 1978 through 2001, and Conception Creek, Conception Island from 1989 through 2001 - to generate estimates of annual survival probabilities. We employ a joint analysis of live-recapture and dead-recovery data (Burnham model) to generate estimates of true survival and permanent emigration probabilities for the Union Creek sampling population. Because fewer dead-recovery data were available for the Conception Creek sampling population, we used a Cormack-Jolly-Seber modeling approach to estimate an apparent annual survival probability of 0.680 , which confounds mortality and permanent emigration. Our best estimate of true annual survival probability for Union Creek green turtles, protected from humaninduced mortality, is 0.891 . High survival probabilities in immature stages are necessary for species such as sea turtles with long lifespans and late sexual maturity to maintain stable populations. After green turtles emigrated from Union Creek, annual survival probability declined to 0.761 as the turtles were no longer protected from human-induced mortality, demonstrating the negative effect of this mortality on the future of green turtle populations in the Caribbean. This study reports the first application of the joint analysis of live-recapture and dead-recovery data to sea turtle populations and demonstrates the advantages of this modeling approach.
\end{abstract}

KEY WORDS: Bahamas · Burnham model · Capture-mark-recapture · Caribbean · Cormack-JollySeber model $\cdot$ Emigration $\cdot$ Green turtle $\cdot$ Survival

\section{INTRODUCTION}

Populations of green turtles Chelonia mydas have suffered major declines worldwide, largely as a result of exploitation by humans. In the Greater Caribbean, current green turtle populations are estimated to represent 3 to $7 \%$ of the population levels prior to human exploitation (Jackson et al. 2001). In response to this severe depletion, conservation and management programs have been initiated. However, life-history char- acteristics of green turtles make them difficult to protect, and our incomplete knowledge of their biology is a major obstacle to management programs. Green turtles are long-lived and slow growing (Bjorndal et al. 2000, Chaloupka 2002). During their immature stages, green turtles undertake extensive developmental migrations. It is believed that green turtles spend their first years of life in oceanic habitats during which they may cross ocean basins (Bolten 2003). After this early oceanic stage, they recruit to neritic habitats and, at 
least in the Atlantic, continue to move extensively among foraging grounds. Immature green turtles on these foraging grounds are mixed stocks from a number of rookeries in the Atlantic (Lahanas et al. 1998, Bass \& Witzell 2000). These extensive and often obscure movements increase the difficulty of studying the ecology of these populations and estimating demographic parameters. One of the major gaps in our knowledge of population dynamics for all species of sea turtles is survival probabilities, particularly for immature stages (Chaloupka \& Musick 1997, Heppell et al. 2003).

Estimates of survival probabilities for populations of immature sea turtles have been based on analytical techniques that confound mortality and permanent emigration (Frazer 1987, Heppell et al. 1996, TEWG (Turtle Expert Working Group) 2000, Epperly et al. 2001, Chaloupka \& Limpus 2002, Bjorndal et al. 2003). That is, the analyses cannot distinguish between a turtle that has died and one that has permanently emigrated from the population. These analyses generate estimates of apparent survival probability $(\Phi)$

$$
\Phi=S(1-e)
$$

where $S$ is true survival probability and $e$ is probability of permanent emigration.

The confounding of mortality and permanent emigration is not a great problem for estimating survival probabilities for immature green turtles and loggerheads where probability of permanent emigration is low, such as in the southern Great Barrier Reef, Australia (Chaloupka \& Limpus 2002, in press). In the southern Great Barrier Reef, once turtles recruit from oceanic to neritic foraging grounds, they tend to establish an area of residency and remain there. In the Atlantic system, however, these species undergo developmental migrations, during which individuals travel among areas separated by distances of up to hundreds or thousands of $\mathrm{km}$ and may remain at different sites for a few months to a few years before moving on. Other than the southward migrations undertaken by sea turtles as water temperatures drop in the northern latitudes, the patterns and causes of these migrations remain elusive. What is clear is that high rates of emigration can often result in estimates of apparent survival that are substantially lower than true survival (see Francis \& Cooke 1993 for an example concerning snow goose survival estimation). Although estimates of apparent survival are very useful for seting the lower boundary of $S$, estimates of $S$ are of greater value. Models that enable the joint analysis of live-recapture and dead-recovery data for a single population can be used to distinguish between mortality and permanent emigration (Burnham 1993, Barker 1997, Catchpole et al. 1998). These Burnham-type models are applicable when the study comprises only a single population and enable robust estimation of true survival and other useful demographic parameters such as fidelity $(F=1-e)$, which is the probability that an animal remains in the study area between 2 successive sampling occasions.

In this paper, we report results from 2 long-term capture-mark-recapture studies of immature green turtles in the Bahamas. From live-recapture and deadrecovery data for green turtles in Union Creek, Great Inagua, collected from 1978 to 2001, we generate estimates of true survival and fidelity using an extension of the Burnham model (Burnham 1993), implemented here using the program MARK, that allows joint analysis of live-recapture and dead-recovery data with ageclass-specific (= tag-cohort-age-specific, in this study) and time-dependent effects (White \& Burnham 1999). The dead-recovery data are based on tags returned to us from throughout the Greater Caribbean that we had applied to Union Creek green turtles which later emigrated and were killed. The other study was conducted in Conception Creek, Conception Island, from 1989 to 2001. Because we have received relatively few deadrecoveries for this population, we could not use a Burnham model, and instead we generated estimates of apparent survival probability using a Cormack-JollySeber modeling approach (Lebreton et al. 1992) implemented using MARK (White \& Burnham 1999).

\section{MATERIALS AND METHODS}

Data collection. This analysis is part of an ongoing study of the ecology of immature green turtles in the Bahamas. Data reported here are from 2 green turtle foraging grounds: Union Creek and Conception Creek. Union Creek is on the north coast of Great Inagua, the southernmost island in the Bahamas $\left(21.17^{\circ} \mathrm{N}, 73.57^{\circ} \mathrm{W}\right)$. Conception Island $\left(23.82^{\circ} \mathrm{N}\right.$, $75.10^{\circ} \mathrm{W}$ ) in the central Bahamas has the appearance of an atoll-it is a narrow strip of land surrounding Conception Creek. In the Bahamas, a creek is a saltwater bay, not associated with freshwater, as the name would suggest in other countries. Union Creek Reserve and Conception Island are both within the Bahamas National Park system, and green turtles within their boundaries have legal protection from exploitation. Harvest of green turtles in Union Creek is, at most, extremely rare (Bahamas National Trust Wardens pers. comm.). Enforcement on the uninhabited Conception Island is problematic, and green turtles are occasionally removed from Conception Creek by humans from neighboring islands or on visiting yachts (S. Connett pers. comm., Bjorndal \& Bolten pers. obs.). Union Creek is approximately $20 \mathrm{~km}^{2}$ in area, is surrounded 
by and interspersed with mangroves, and has pastures of the seagrass Thalassia testudinum, the primary diet plant of green turtles in the Greater Caribbean (Bjorndal 1997). The habitat of Conception Creek is similar to that of Union Creek, except Conception Creek is smaller in area and has more shallow water depths.

Immature green turtles enter Union Creek or Conception Creek and then emigrate, after varying lengths of time, to other habitats throughout the Greater Caribbean prior to the onset of sexual maturity. Based on mtDNA sequences, both study populations are mixed stocks derived from a number of green turtle rookeries in the Atlantic (Lahanas et al. 1998, Bjorndal \& Bolten unpubl. data). Our study of the ecology of the Union Creek sampling population began in 1975; data presented here were collected each year from 1978 through 2001 except for 1981, 1995 and 1999. Data collection was initiated in 1989 in Conception Creek and continued each year through 2001. In both study areas, we captured green turtles by jumping on them from the bow of a motorboat, following a brief chase. Turtles were tagged with flipper tags bearing an identification number, return address, and offer of a reward for the return of the tag (printed in English and Spanish). To maintain individual identification of turtles, 2 to 4 tags were applied to each turtle and tags were replaced as needed upon recapture. Straight carapace length $( \pm 0.1 \mathrm{~cm})$ was measured from the anterior midpoint of the nuchal scute to the posterior tip of the longer of the pair of posterior marginal scutes. No indication of the disease fibropapillomatosis has ever been observed in green turtles at either study site. At Union Creek, the annual sampling period was a single 7 to $10 \mathrm{~d}$ interval with approximately equal sampling effort among years; K. A. Bjorndal and A. B. Bolten collected all data. Data collection at Conception Creek has been conducted in collaboration with the semester-at-sea program of St. George's School (Newport, Rhode Island, USA) aboard the sailing vessel 'Geronimo'. Annual sampling periods were more variable in duration and periodicity, but capture effort was approximately equal among years with an average of $7 \mathrm{~d} \mathrm{yr}^{-1}$. All data collected in Conception Creek within a calendar year were combined for that year. There is no evidence, based on tag returns, of turtles moving between the Union Creek and Conception Creek sampling populations. In this paper we will refer to the 2 sampling groups as populations.

Data analyses. We used the Cormack-Jolly-Seber modeling approach advocated by Lebreton et al. (1992). All modeling was implemented using MARK (Version 2.1) with logit link function to constrain estimates between 0 and 1 (White \& Burnham 1999, Cooch \& White 2001, available at: http://canuck.dnr.cornell. edu/mark/). We assessed live-recaptures-only models and combined live-recaptures and dead-recoveries models (Burnham models; Burnham 1993). We used an extension of the Burnham model to allow estimation of both age-dependent and time-dependent parameters rather than just time-dependent parameters implemented using MARK. A similar extension to the Burnham model has been developed by Catchpole et al. (1998). Live-recaptures-only models generate estimates of apparent survival probability $(\Phi)$, which is the probability that a turtle has not died or emigrated from the study population, and recapture probability $(\rho)$, which is the probability that a turtle that is available for capture in the study population is caught. Combined live-recaptures and dead-recoveries models generate estimates for true survival probability $(S)$, which is the probability that a turtle has not died; recapture probability $(\rho)$; fidelity probability $(F)$, which is the probability that a turtle remains in the study area; and recovery probability $(r)$, which is the probability that a tagged turtle that dies is found and also that the tag is returned to us. This last probability is important, because not all tags on killed turtles are are returned to us by fishermen. In addition to being lost in the mail, tags may not be returned because the fisherman (1) does not understand the message on the tag, (2) fears revealing the capture if the turtle was taken illegally, (3) does not have sufficient funds to mail the tag, or (4) is indifferent. For the Burnham model, we assume that there is no substantive bias in the report rates of dead turtles from different mortality sources (Francis \& Cooke 1993).

Goodness of fit (GoF) of the models was evaluated in a series of tests. First, we tested the full parameter Cormack-Jolly-Seber model (time-dependent survival and recapture probabilities) using RELEASE TEST2+3 within MARK (White \& Burnham 1999) to evaluate assumptions that marked turtles had the same recapture and survival probabilities (Burnham et al. 1987, Lebreton et al. 1992). Next we used UCARE (Choquest et al. 2001), which implements the extended form of TEST2+3 derived originally by Burnham et al. (1987), to evaluate recapture heterogeneity with TEST2.Ct (Pradel 1993). TEST2.Ct (Pradel 1993) tests for specific behavioral patterns, such as temporary emigration or recapture heterogeneity, that mimic trap dependence. More details of the application of this test were provided in Pradel et al. (1997) and Chaloupka et al. (1999), with specific application to sea turtle survival probability estimation in Chaloupka \& Limpus (2002). Selection of the best model from a series of models was based on the quasi-likelihood corrected form of the Akaike Information Criterion (QAICc) (Burnham et al. 1995, Anderson et al. 1998). The GoF of the best fit model selected by QAICc was then assessed in absolute terms using a parametric bootstrap approach 
implemented in MARK. Application of these procedures to capture-mark-recapture studies in sea turtles has been reviewed in greater detail elsewhere (Chaloupka 2000, Chaloupka \& Limpus 2002, 2003).

\section{RESULTS}

\section{Turtle captures and tag recoveries}

In Union Creek from 1978 through 2001, 764 individual green turtles were captured, with a total of 1579 captures. Individual turtles were captured between 1 and 10 times (Fig. 1a). Mean straight carapace length at initial capture was $46.7 \mathrm{~cm}(\mathrm{SD}=10.3, \mathrm{n}=764)$. Straight carapace length ranged from 25 to $84 \mathrm{~cm}$ for all 1579 captures. In Conception Creek from 1989 to 2001, 196 individual green turtles were captured between 1 and 7 times (Fig. 1b), with a total of 401 turtle captures (counting only the first capture of each turtle in each year). Mean straight carapace length at initial
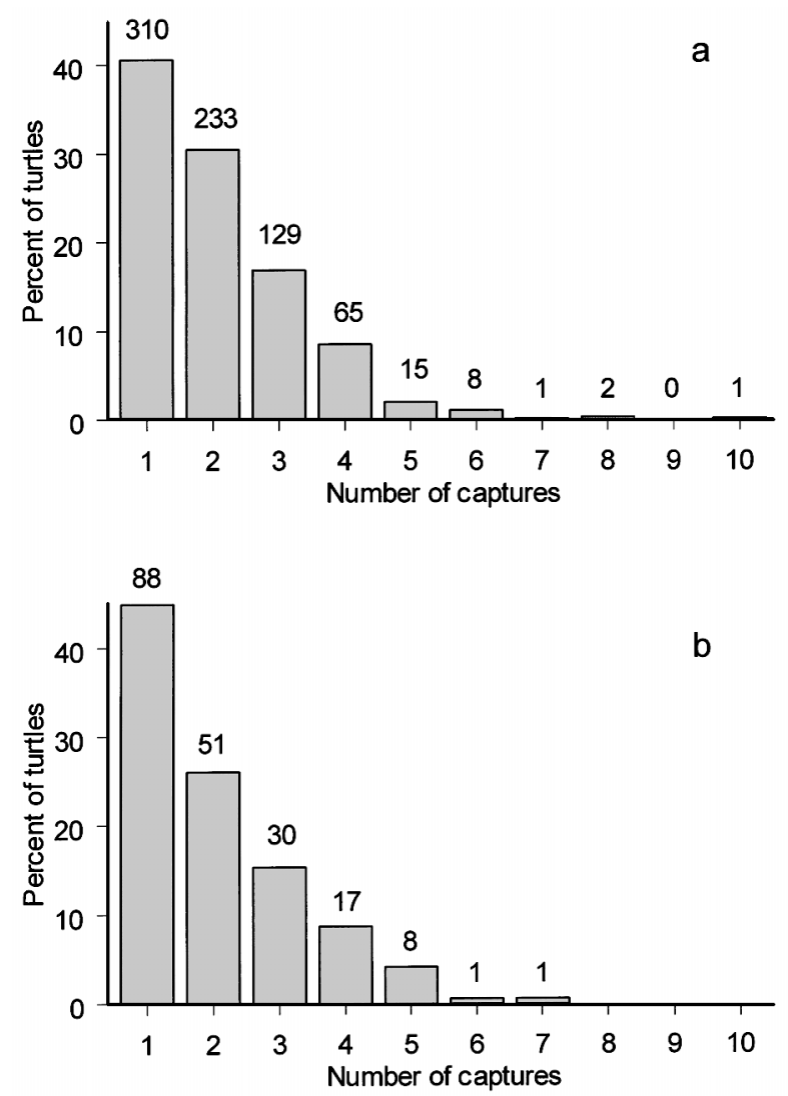

Fig. 1. Chelonia mydas. Number of times each green turtle was captured in (a) Union Creek, Great Inagua 1978 through 2001 ( $\mathrm{n}=764$ turtles and 1579 captures), and (b) Conception Creek, Conception Island 1989 through 2001 (n = 196 turtles and 401 captures). Numbers above each bar are sample sizes capture was $34.1 \mathrm{~cm}(\mathrm{SD}=6.7, \mathrm{n}=196)$. Straight carapace lengths of green turtles in Conception Creek ranged from 22 to $64 \mathrm{~cm}$ for all 401 captures. Tag recoveries away from the study areas were reported to us from throughout the Greater Caribbean (Bjorndal \& Bolten unpubl. data) for 68 green turtles from Union Creek and 9 green turtles from Conception Creek, representing 8.9 and $4.6 \%$ of the green turtles in the Union Creek and Conception Creek samples, respectively. Tags applied to green turtles in Union Creek were returned from the Bahamas, Colombia, Costa Rica, Cuba, Dominican Republic, Haiti, Honduras, Nicaragua, Panama, and Venezuela. Tags applied to green turtles in Conception Creek were returned from Cuba.

\section{Union Creek model}

When the GoF tests were run on the full parameter Cormack-Jolly-Seber model (time-dependent $\Phi$ and $\rho$ ) for Union Creek, the model passed TEST2 of RELEASE $\left(\chi^{2}=20.48, \mathrm{df}=20, \mathrm{p}=0.428\right)$ and TEST2.Ct (trapdependence statistic $=0.163, \mathrm{p}=0.87)$, but failed TEST3 of RELEASE $\left(\chi^{2}=84.23, \mathrm{df}=34, \mathrm{p}<0.001\right)$. The model passed TEST3. $\operatorname{Sm}\left(\chi^{2}=20.85, \mathrm{df}=15, \mathrm{p}=0.142\right)$, indicating that transience was not a problem. Further inspection of the results of TEST3 indicated that failure was due to TEST3.SR $\left(\chi^{2}=63.38, \mathrm{df}=19, \mathrm{p}<0.001\right)$, indicating that survival probabilities were age dependent and thus an age-class model should be used instead of a time-dependent survival probability model. Therefore, we concluded that we could proceed with evaluation of age-class models. Because we do not know the ages of green turtles in Union Creek, we used tag-cohort-age, for which 0 was set as the year in which the turtle was first tagged in Union Creek. The data on dead-recoveries allowed us to run a series of age-class (= tag-cohort-age-class) models with both live-recaptures and dead-recoveries (Burnham models; Table 1). Burnham models have the advantage of generating estimates of true survival and fidelity probabilities instead of apparent survival probabilities if there is permanent emigration or some non-random form of temporary emigration.

The model with the best fit based on QAICC is a Burnham model with 4 tag-cohort-age classes, with age-dependent $S$, time-dependent $\rho$, time-dependent $r$, and age-dependent $F$ (Table 1 ). The 4 tag-cohortage-class model has a slightly lower QAICc than the 5 tag-cohort-age-class model (0.14 difference), and a correspondingly higher QAICc weight. Parametric bootstrap GoF tests indicated that the 4 tag-cohort-ageclass model had an acceptable fit, whereas the 5 tagcohort-age-class model did not (alpha $=0.05$ ). The only 
Table 1. Chelonia mydas. Modeling summary for immature green turtles foraging in Union Creek based on a 24 yr (1978 to 2001$)$ capture-mark-recapture study. Model parameters are survival probability $(S)$, recapture probability $(\rho)$, recovery probability $(r)$, and fidelity probability $(F)$. Par: number of estimable parameters, QAICc: the quasi likelihood corrected Akaike Information Criterion, Deviance: relative deviance, Age: tag-cohort-age-dependent, Time: time-dependent, Const: constant

\begin{tabular}{|c|c|c|c|c|c|c|c|c|c|}
\hline $\begin{array}{l}\text { Model } \\
\text { no. }\end{array}$ & $\begin{array}{l}\text { Tag-cohort- } \\
\text { age classes }\end{array}$ & $S$ & $\rho$ & $r$ & $F$ & Par & QAICc & $\begin{array}{l}\text { QAICc } \\
\text { weight }\end{array}$ & Deviance \\
\hline 1 & 4 & Age & Time & Time & Age & 46 & 3833.5 & 0.367 & 923.2 \\
\hline 2 & 5 & Age & Time & Time & Age & 48 & 3833.6 & 0.343 & 919.1 \\
\hline 3 & 6 & Age & Time & Time & Age & 50 & 3836.9 & 0.068 & 918.1 \\
\hline 4 & 7 & Age & Time & Time & Age & 52 & 3838.3 & 0.034 & 915.2 \\
\hline 5 & 8 & Age & Time & Time & Age & 54 & 3839.7 & 0.017 & 912.3 \\
\hline 6 & 4 & Age & Time & Time & Time & 59 & 3839.8 & 0.016 & 901.6 \\
\hline 7 & 9 & Age & Time & Time & Age & 56 & 3841.4 & 0.007 & 909.7 \\
\hline 8 & 10 & Age & Time & Time & Age & 57 & 3842.8 & 0.003 & 909.0 \\
\hline 9 & 4 & Age & Time & Time & Const & 43 & 3845.6 & 0.001 & 941.7 \\
\hline 10 & 4 & Age & Time & Age & Age & 30 & 3846.2 & 0.001 & 969.5 \\
\hline 11 & 4 & Age & Time & Const & Age & 29 & 3850.1 & 0.000 & 975.5 \\
\hline 12 & 3 & Age & Time & Time & Age & 44 & 3855.2 & 0.000 & 949.2 \\
\hline 13 & 2 & Age & Time & Time & Age & 42 & 3874.3 & 0.000 & 972.5 \\
\hline 14 & 4 & Age & Const & Time & Age & 27 & 4151.2 & 0.000 & 1280.7 \\
\hline 15 & 4 & Age & Age & Time & Age & 30 & 4153.4 & 0.000 & 1276.8 \\
\hline 16 & 4 & Age & Age & Age & Age & 15 & 4169.4 & 0.000 & 1323.6 \\
\hline
\end{tabular}

substantial difference in the estimates of $S$ and $F$ between the 2 models is a delay of $1 \mathrm{yr}$ in the decline of $S$ in the 5 tag-cohort-age-class model.

The estimates of $S$ and $F$ for the 4 tag-cohort-age classes are given in Table 2, and plotted in Fig. 2,

Table 2. Chelonia mydas. Estimates for true survival $(S)$ and fidelity $(F)$ probabilities for immature green turtles foraging in Union Creek from a 4 tag-cohort-age-class Burnham model (live-recaptures and dead-recoveries; Table 1, Model 1). For Union Creek, apparent survival probability $(\Phi)$ is calculated $(S \times F)$. Estimate for $\Phi$ for immature green turtles foraging in Conception Creek is from a live-captures-only model with constant $\Phi$ (Table 3, Model 1)

\begin{tabular}{|ccccc|}
\hline Parameter & $\begin{array}{c}\text { Tag-cohort- } \\
\text { age classes }\end{array}$ & & & \\
\hline Union Creek & & & & \\
$S$ & 1 & 0.909 & 0.034 & $0.82-0.96$ \\
$S$ & 2 & 0.853 & 0.051 & $0.72-0.93$ \\
$S$ & 3 & 0.911 & 0.041 & $0.79-0.96$ \\
$S$ & 4 & 0.761 & 0.033 & $0.69-0.82$ \\
$F$ & 1 & 0.896 & 0.041 & $0.78-0.95$ \\
$F$ & 2 & 0.882 & 0.064 & $0.69-0.96$ \\
$F$ & 3 & 0.852 & 0.060 & $0.69-0.94$ \\
$F$ & 4 & 0.671 & 0.040 & $0.59-0.74$ \\
$\Phi$ & 1 & 0.814 & & \\
$\Phi$ & 2 & 0.752 & & \\
$\Phi$ & 3 & 0.776 & & \\
$\Phi$ & 4 & 0.510 & & \\
Conception Creek & & & & \\
$\Phi$ & - & 0.680 & 0.024 & $0.63-0.73$ \\
\hline
\end{tabular}

where $F$ is converted to permanent emigration probability $(e=1-F)$. The $95 \%$ CI values plotted for $e$ were calculated by subtracting from 1 the upper and lower $95 \%$ CI values for $F$ (Table 2 ).

The estimates of $\rho$ for each year ranged from 0.262 to 0.884 (geometric mean $=0.549$ ), which are high for capture-mark-recapture studies (see Pollock et al. 1990). Estimates of $r$ for each year ranged from 0.021 to 0.295 (geometric mean $=0.088)$.

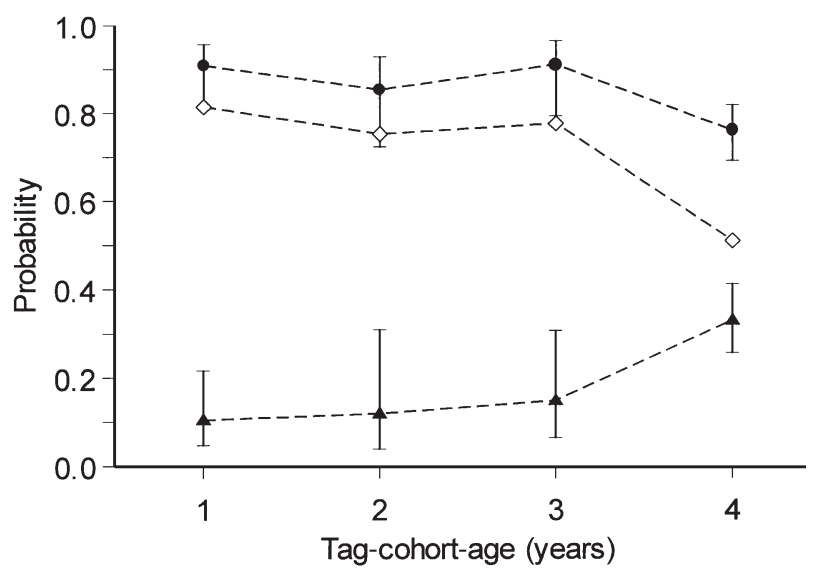

Fig. 2. Chelonia mydas. Estimates of true survival probabilities $\left(S_{;} \bullet\right)$, apparent survival probabilities $\left(\Phi_{;} \diamond\right)$, and permanent emigration probability $\left(e=1\right.$ - fidelity $\left.[F]_{;} \mathbf{\Delta}\right)$ for 4 tagcohort-age classes (yr) of green turtles in Union Creek. Vertical bars represent $95 \%$ CIs for $S$ and $e$ 


\section{Conception Creek model}

When GoF tests were run on the full parameter Cormack-Jolly-Seber model (time-dependent $\Phi$ and $\rho$ ) for Conception Creek, the model passed TEST2+3 in RELEASE $\left(\chi^{2}=33.33, \mathrm{df}=30, \mathrm{p}=0.308\right)$. Therefore, there was no evidence of age dependence or transience. However, there was strong evidence of heterogeneity of recapture probabilities (UCARE TEST2.Ct, trap-dependence statistic $=-2.94, p=0.003)$. The negative value of the trap-dependence statistic indicates that the turtles are 'trap happy;' that is, previously captured turtles have a higher recapture probability. Trapdependent effects can be difficult to interpret (Pradel 1993); Lebreton et al. (1992) found 'trap-dependence' in their case study involving flamingos Phoenicopterus ruber, although the flamingos were not physically recaptured, just resighted. The only explanation for trap-happy green turtles that we can propose is that the data structure mimics trap-happiness because of the very high recapture probability in Conception Creek resulting from its small area and shallow waters. We concluded that we could proceed with evaluation of reduced Cormack-Jolly-Seber models (Table 3), but that results should be interpreted with caution because trap-dependence could result in positively biased estimates of survival (Pradel 1993).

The model with the best fit was a live-captures-only model with constant survival and time-dependent recapture probability (Table 3 ). The parametric GoF test indicated an acceptable overall model fit (alpha $=0.05$ ) for this model. Burnham models gave unrealistically high estimates of $S$ (approaching 1.0). We believe the failure of Burnham models resulted from the low number of dead recoveries. Because the best model was a live-captures only model, our estimate of survival probability is $\Phi$, which confounds mortality (both natural and human-induced) and permanent emigration (Table 2). We believe that permanent emigration is high in the Conception Creek population based on tag

Table 3. Chelonia mydas. Cormack-Jolly-Seber modeling summary for immature green turtles foraging in Conception Creek based on a 13 yr (1989 to 2001) capture-mark-recapture study. $\Phi$ : apparent survival probability, $\rho$ : recapture probability, Par: number of estimable parameters, QAICc: quasi likelihood corrected Akaike Information Criterion, Deviance: relative deviance, Time: time-dependent

\begin{tabular}{|ccccccc|}
\hline $\begin{array}{c}\text { Model } \\
\text { no. }\end{array}$ & $\Phi$ & $\rho$ & Par & QAICc & $\begin{array}{l}\text { QAICc } \\
\text { weight }\end{array}$ & Deviance \\
\hline 1 & Constant & Time & 13 & 775.1 & 0.958 & 193.2 \\
2 & Time & Time & 23 & 782.5 & 0.023 & 178.4 \\
3 & Time & Constant & 12 & 783.0 & 0.018 & 203.3 \\
4 & Constant & Constant & 2 & 788.0 & 0.001 & 229.1 \\
\hline
\end{tabular}

returns, sightings during swim surveys off the coast of Conception Island of turtles tagged in Conception Creek, and the small number of turtles above $50 \mathrm{~cm}$ carapace length in the creek. The estimates of recapture probability for each year ranged from 0.328 to 0.940 (geometric mean $=0.590$ ), which are high for capture-mark-recapture studies as reported for the Union Creek population.

\section{DISCUSSION}

Estimates of $S$ and permanent emigration probabilities $(e=1-F)$ exhibit an inverse relationship (Fig. 2) in the Union Creek population. This relationship reflects the fact that when green turtles leave the Union Creek Reserve and are exposed to exploitation by humans, their probability of survival declines. That is, by tag-cohort-age-class 4, emigration probability has increased to 0.330 and survival has dropped to 0.761 . Most of the human-induced mortality, as recorded by tag returns, comes soon after the turtles leave Union Creek, primarily within the first year. Our best estimate of the interval between departure from Union Creek and death is the number of yr from the time the turtle was last seen in Union Creek to the time it was killed and the tag reported to us (Fig. 3). Because the year in which the turtle was last seen in Union Creek is not necessarily the year of departure, the time intervals in Fig. 3 are maximum estimates.

Our estimates of $S$ include both natural and humaninduced sources of mortality. Our best estimate for $S$ in immature green turtles under natural conditions, with human exploitation excluded, is 0.891 , the geometric mean of $S$ for the first 3 tag-cohort-age classes. During these tag-cohort-age classes, turtles have a high probability of remaining in Union Creek, as indicated by the high probabilities of fidelity ranging from 0.852 to 0.896 (Table 2). Therefore most mortality in these tagcohort-age classes will be from natural predators - sharks and barracudasand disease. Evidence of predation attempts has been noted in Union Creek, such as the loss of a flipper from an individual turtle between our captures.

The $S$ value of 0.761 in tag-cohortage-class 4 is higher than $S$ for green turtles exposed to the full extent of human-induced mortality in the Caribbean. Many of the turtles in tagcohort-age-class 4 were still in Union Creek, protected from human exploitation, and thus enjoyed higher 


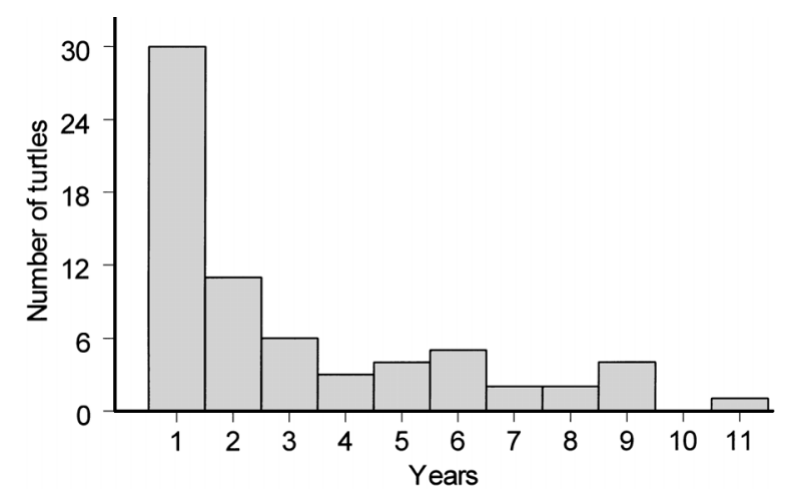

Fig. 3. Chelonia mydas. Interval (yr) between the last sighting of a green turtle in Union Creek and its reported death $(n=68)$

survival. Green turtle populations outside of Union Creek have lower survival probabilities.

Estimates of $\Phi$ or apparent survival can be calculated $(=S \times F)$ for Union Creek green turtles (Table 2). These values reveal the effect that confounding mortality and emigration can have on estimates of survival probabilities, and emphasize the advantage of incorporating dead-recoveries into capture-mark-recapture studies to generate estimates of true, rather than apparent, survival. Permanent emigration was low in the first 3 tag-cohort-age classes (Fig. 2), and, as a result, the calculated estimate of $\Phi$ lies within or only slightly below the $95 \%$ CI of $S$ for the first 3 tag-cohort-age classes. However, because emigration increased in tag-cohortage-class 4 , the estimate of $\Phi$ is much lower than $S$ for that tag-cohort-age class. It is important to distinguish between the role that increased permanent emigration played in the decline in $S$ and in the decline in $\Phi$ for tag-cohort-age-class 4. $S$ declined because, as green turtles emigrated from Union Creek, they were exposed to higher human-induced mortality, which lowered their probability of survival. $\Phi$ declined because all turtles that emigrated were included in the estimate of mortality.

Calculating $\Phi$ for Union Creek green turtles also allows comparison with the estimate of $\Phi$ generated for Conception Creek green turtles and other populations of sea turtles, bearing in mind that our estimate of $\Phi$ for Conception Creek green turtles may be positively biased because of trap-happiness. We would expect that survival probabilities for green turtles in Union Creek and Conception Creek would be fairly similar because these populations represent similar stages in the developmental migrations of green turtles in the Greater Caribbean, and they occupy similar habitats. The estimate of $\Phi$ for Conception Creek green turtles (0.680) is within the range of values for Union Creek, and the geometric mean (0.702) of $\Phi$ for Union Creek green turtles lies within the $95 \%$ CI for the estimate of $\Phi$ for Conception Creek green turtles (Table 2).

Survival probabilities will vary among populations and life-stages within and among sea turtle species because of the differences in environments and sources of mortality. All survival probabilities for wild populations of immature sea turtles of which we are aware are presented in Table 4 . These estimates are all directly derived estimates (estimates not derived by fitting population models) of apparent survival proba-

Table 4. Estimates of apparent survival probability $(\Phi)$ of wild populations of immature sea turtles, expressed as point estimate or mean $(95 \%$ CI), unless noted. CCL: curved carapace length; sGBR: southern Great Barrier Reef; CJS: Cormack-Jolly-Seber model; B: Burnham model; CC: catch-curve analysis

\begin{tabular}{|c|c|c|c|c|}
\hline Species & Location and habitat & $\Phi$ & Method & Source \\
\hline Green turtle (35 to $65 \mathrm{~cm} \mathrm{CCL)}$ & sGBR, Australia, neritic & $\begin{array}{c}0.880 \\
(0.835-0.927)\end{array}$ & CJS & $\begin{array}{l}\text { Chaloupka \& Limpus } \\
\text { (2003) }\end{array}$ \\
\hline Green turtle (65 to $90 \mathrm{~cm} \mathrm{CCL)}$ & sGBR, Australia, neritic & $\begin{array}{c}0.847 \\
(0.790-0.908)\end{array}$ & CJS & $\begin{array}{l}\text { Chaloupka \& Limpus } \\
\text { (2003) }\end{array}$ \\
\hline Green turtle & Union Creek, Bahamas, neritic & $\begin{array}{c}\text { Range = } \\
0.510-0.814\end{array}$ & B & Current study \\
\hline Green turtle & Conception Creek, Bahamas, neritic & $\begin{array}{c}0.680 \\
(0.631-0.725)\end{array}$ & CJS & Current study \\
\hline Loggerhead & North Atlantic, oceanic & 0.720 & $\mathrm{CC}$ & Bjorndal et al. (2003) \\
\hline Loggerhead & Southeast US, neritic & 0.695 & $\mathrm{CC}$ & Frazer (1987) \\
\hline Loggerhead & Southeast US, neritic & 0.893 & $\mathrm{CC}$ & Epperly et al. (2001) \\
\hline Loggerhead & sGBR, Australia, neritic & 0.830 & CJS & Heppell et al. (1996) \\
\hline Loggerhead & sGBR, Australia, neritic & $\begin{array}{c}0.859 \\
(0.828-0.885)\end{array}$ & CJS & $\begin{array}{l}\text { Chaloupka \& Limpus } \\
\text { (2002) }\end{array}$ \\
\hline Loggerhead & sGBR, Australia, neritic & $\begin{array}{c}0.918 \\
(0.88-0.96)\end{array}$ & $\mathrm{CJS}^{\mathrm{a}}$ & $\begin{array}{l}\text { Chaloupka \& Limpus } \\
\text { (2002) }\end{array}$ \\
\hline Kemp's ridley & Southeast US, neritic & $\begin{array}{c}\text { Mode }=0.5 \\
\text { Range }=0.3-0.8\end{array}$ & $\mathrm{CC}$ & TEWG (2000) \\
\hline
\end{tabular}


bilities. The values for immature green turtles in Australia (Chaloupka \& Limpus in press) are more similar to our estimates of $S$ than to our values of $\Phi$ because of the low permanent emigration exhibited by these size classes in Australia (Chaloupka \& Limpus 2003).

If our estimates of $S$ for the first 3 tag-cohort-age classes in Union Creek (geometric mean $=0.891$ ) represent natural survival probabilities for green turtles in the Caribbean region without human-induced mortality, and if our estimate of $S$ for tag-cohort-ageclass 4 (0.761) is the upper bound of survival for green turtles experiencing human-induced mortality, the dire situation facing Caribbean green turtles is clear. Species characterized by long life and late sexual maturity require very high survival throughout immature stages to maintain populations (Congdon et al. 1993, Crouse 1999, Chaloupka 2002). The substantial drop in survival probabilities from 0.891 to $<0.761$ would have a major effect on population stability and growth in Caribbean green turtles. Chaloupka (2002), in a comprehensive application of fractional factorial sampling approaches to sensitivity analyses and evaluation of sea turtle population dynamics, showed that even a slight reduction in survival probabilities for green turtle populations would result in a substantial drop in expected population abundance.

More estimates for survival probability for sea turtle populations are needed. A number of longterm capturemark-recapture studies now underway could yield valuable estimates. This study has reported the first application of the joint analysis of live-recapture and dead-recovery data to sea turtle populations and demonstrated the advantages of this modeling approach.

Acknowledgements. The long-term study at Union Creek would not have been possible without the assistance of the Bahamas National Trust wardens on Great Inagua: H. Nixon, R. Burrows, J. Nixon, S. Nixon, and T. Major. The Conception Creek study would not have been possible without the work of S. and B. Connett, D. Hayes, C. McNally, and the students of St George's School who participated in the semester-at-sea program on the 'Geronimo'. We are grateful to the Bahamas National Trust for their support and permission to conduct research in their reserves, and to the Bahamas Department of Fisheries for their support and permits to conduct research in the Bahamas. The research has been funded by the US National Marine Fisheries Service, Disney Wildlife Conservation Fund, National Fish and Wildlife Foundation, and the Caribbean Conservation Corporation. Morton Bahamas Ltd., the US Coast Guard, and the people of Mathew Town, Inagua, have provided invaluable logistic support for the Union Creek study. We thank C. Lagueux of the Wildlife Conservation Society, the Miskitu and Creole communities in Nicaragua, and F. Moncada of the Centro de Investigaciones Pesqueras, Cuba, for assistance with tag returns; G. White for valuable advice on Program MARK; and P. Eliazar for assistance with data management. All work was conducted in compliance with the Institutional Animal Care and Use Committee, University of Florida.

\section{LITERATURE CITED}

Anderson DR, Burnham KP, White GC (1998) Comparison of Akaike Information Criterion and consistent Akaike Information Criterion for model selection and statistical inference from capture-recapture studies. J Appl Stat 25: 263-282

Barker RJ (1997) Joint modeling of live-recapture, tagresight, and tag-recovery data. Biometrics 53:666-677

Bass AL, Witzell WN (2000) Demographic composition of immature green turtles (Chelonia mydas) from the east central Florida coast: evidence from mtDNA markers. Herpetologica 56:357-367

Bjorndal KA (1997) Foraging ecology and nutrition of sea turtles. In: Lutz PL, Musick JA (eds) The biology of sea turtles. CRC Press, Boca Raton, FL, p 199-231

Bjorndal KA, Bolten AB, Chaloupka MY (2000) Green turtle somatic growth model: evidence for density dependence. Ecol Appl 10:269-282

Bjorndal KA, Bolten AB, Martins HR (2003) Estimates of survival probabilities for oceanic-stage loggerhead sea turtles (Caretta caretta) in the North Atlantic. Fish Bull (in press)

Bolten AB (2003) Variation in sea turtle life history patterns: neritic versus oceanic developmental stages. In: Lutz PL, Musick JA, Wyneken J (eds) The biology of sea turtles, Vol 2. CRC Press, Boca Raton, FL, p 243-257

Burnham KP (1993) A theory for combined analysis of ring recovery and recapture data. In: Lebreton JD, North PM (eds) Marked individuals in the study of bird population. Birkhäuser Verlag, Basel, p 199-213

Burnham KP, Anderson DR, White GC, Brownie C, Pollock KH (1987) Design and analysis methods for fish survival experiments based on release-recapture. Am Fish Soc Monogr 5:1-437

Burnham KP, White GC, Anderson DR (1995) Model selection strategy in the analysis of capture-recapture data. Biometrics 51:888-898

Catchpole EA, Freeman SN, Morgan BJT, Harris MP (1998) Integrated recovery/recapture data analysis. Biometrics 54:33-46

Chaloupka M (2000) Capture-recapture modeling of sea turtle population abundance. In: Bjorndal KA, Bolten AB (eds) Proceedings of a workshop on assessing abundance and trends for in-water sea turtle populations. NOAA Technical Memorandum NMFS-SEFSC-445, p 16-35

Chaloupka M (2002) Stochastic simulation modelling of southern Great Barrier Reef green turtle population dynamics. Ecol Model 148:79-109

Chaloupka MY, Limpus CJ (2002) Survival probability estimates for the endangered loggerhead sea turtle resident in southern Great Barrier Reef waters. Mar Biol 140: 267-277

Chaloupka M, Limpus CJ (2003) Estimates of sex- and stagespecific survival probabilities for green turtles resident in southern Great Barrier Reef waters. Mar Biol (in press)

Chaloupka MY, Musick JA (1997) Age, growth, and population dynamics. In: Lutz PL, Musick JA (eds) The biology of sea turtles. CRC Press, Boca Raton, FL, p 233-276

Chaloupka M, Osmond M, Kaufman G (1999) Estimating seasonal abundance trends and survival probabilities of humpback whales in Hervey Bay (east coast Australia). Mar Ecol Prog Ser 184:291-301

Choquest R, Reboulet AM, Pradel R, Lebreton JD (2001) UCARE User's Guide. Version 3.1. Centre d'Ecologie Fonctionelle et Evolutive, Centre National de la Recherche Scientifique, Montpellier 
Congdon JD, Dunham AE, van Loben Sels RC (1993) Delayed sexual maturity and demographics of Blanding's turtle (Emydoidea blandingii): implications for conservation and management of long-lived organisms. Conserv Biol 7:826-833

Crouse DT (1999) The consequences of delayed maturity in a human-dominated world. Am Fish Soc Symp 23:195-202

Epperly SP, Snover ML, Braun-McNeill J, Witzell WN and 5 others (2001) Stock assessment of loggerhead sea turtles of the western North Atlantic. In: Stock assessments of loggerhead and leatherback sea turtles and an assessment of the impact of the pelagic longline fishery on the loggerhead and leatherback sea turtles of the western North Atlantic. US Dept Commerce, NOAA Tech Mem NMFSSEFSC-455, Miami, FL, p 3-66

Francis CM, Cooke F (1993) A comparison of survival rate estimates from live recaptures and dead recoveries of lesser snow geese. In: Lebreton JD, North PM (eds) Marked individuals in the study of bird population. Birkhäuser Verlag, Basel, p 169-183

Frazer NB (1987) Preliminary estimates of survivorship for wild juvenile loggerhead sea turtles (Caretta caretta). J Herpetol 21:232-235

Heppell SS, Limpus CJ, Crouse DT, Frazer NB, Crowder LB (1996) Population model analysis for the loggerhead sea turtle, Caretta caretta, in Queensland. Wildl Res 23: 143-159

Heppell SS, Crowder LB, Crouse DT, Epperly SP, Frazer NB (2003) Population models for Atlantic loggerheads: past, present and future. In: Bolten $\mathrm{AB}$, Witherington $\mathrm{BE}$ (eds)

Editorial responsibility: Otto Kinne (Editor),

Oldendorf/Luhe, Germany
Loggerhead sea turtles. Smithsonian Institution Press, Washington, DC (in press)

Jackson JBC, Kirby MX, Berger WH, Bjorndal KA and 15 others (2001) Historical overfishing and the recent collapse of coastal ecosystems. Science 293:629-638

Lahanas PN, Bjorndal KA, Bolten AB, Encalada S, Miyamoto MM, Valverde RA, Bowen BW (1998) Genetic composition of a green turtle (Chelonia mydas) feeding ground population: evidence for multiple origins. Mar Biol 130:345-352

Lebreton JD, Burnham KP, Clobert J, Anderson DR (1992) Modeling survival and testing biological hypotheses using marked animals: a unified approach with case studies. Ecol Monogr 62:67-118

Pollock KH, Nichols JD, Brownie C, Hines JE (1990) Statistical inference for capture-recapture experiments. Wildl Monogr 107:1-97

Pradel R (1993) Flexibility in survival analysis from recapture data: handling trap-dependence. In: Lebreton JD, North PM (eds) Marked individuals in the study of bird population. Birkhäuser Verlag, Basel, p 29-37

Pradel R, Hines JE, Lebreton JD, Nichols JD (1997) Capturerecapture survival models taking account of transients. Biometrics 53:88-99

TEWG (Turtle Expert Working Group) (2000) Assessment update for the Kemp's ridley and loggerhead sea turtle populations in the western North Atlantic. US Dept Commerce, NOAA Tech Mem NMFS-SEFSC-444, Miami, FL

White GC, Burnham KP (1999) Program MARK: survival estimation from populations of marked animals. Bird Study 46 (Suppl):120-138

Submitted: September 9, 2002; Accepted: January 7, 2003

Proofs received from author(s): March 27, 2003 